\title{
THE UNDERLYING MOTIVES OF UNIVERSITY STUDENT VOLUNTEERS PARTICIPATING IN COMMUNITY SERVICE ACTIVITIES IN CUSTODIAL SETTINGS IN SOUTH AFRICA: A PHILOSOPHICAL PERSPECTIVE
}

\section{Johan Prinsloo}

Department of Criminology and Security Science, University of South Africa prinsjh@unisa.ac.za

\section{ABSTRACT}

Socrates pronounced that "An unexamined life is not worth living" and maintained the belief that the purpose of human life was personal and spiritual growth. This article explores, against this background, the motives and experiences of 12 student volunteers who assisted with the assessment of sentenced offenders in custodial settings in South Africa, as part of the "third mission" of the Department of Criminology and Security Science at the University of South Africa (Unisa). A case study approach was followed to explore the underlying social context and thereby gain an understanding of the students' experience in terms of their exposure to the correctional milieu. The article relates the student volunteers'experiences regarding their expectations and motives at the outset, their personal experiences and the benefits that involvement in this project holds for them.

Key words: Greek philosophy; third mission; higher education; experiential learning; volunteers; corrections

\section{UNISA $\cong$}




\section{INTRODUCTION}

In his reply to his accusers in the late fifth century BCE (Johnston 2011: 237), and even in the face of death, Socrates pronounced that "An unexamined life is not worth living” (Gerzon 2011). Plato believed that this "existential aspect” is fundamental to education and added that man is never satisfied with any level of social organisation (Scolnicov 1997: 460, 464). It appears that this maxim is still guiding human behaviour in postmodern society.

According to Gerzon (2011), Socrates believed that the purpose of human life is personal and spiritual growth. Gerzon (2011) consequently states that: "We are unable to grow toward greater understanding of our true nature unless we take the time to examine and reflect upon our life." Based on this premise, Gerzon (2011) is also of the belief that: "Deeper contemplation yields understanding of the subconscious programming, the powerful mental software that runs our life." For Plato, to be human is to be "perfectible" and to be able to "go beyond what is empirically given and its extrapolation" (Scolnicov 1997: 464). Aristotle (Howie 1968: 40) made it clear that education involves life-long enquiry and that man should continuously strive to increase and diversify his understanding of his environment, even if he realistically can never know everything. As phrased by Hesiod (Howie 1968: 43):

That man is best who seeks the truth himself;

Good too is he who hearkens to wise counsel.

But who is neither wise himself nor willing

To ponder wisdom, is not worth a straw.

While the author contemplated the motives of a number of student volunteers who rendered community service in South African prisons, the famous "verdict" of Socrates came to mind. In the author's mind, an analogy exists between the context and motives of the volunteers and the recordings of some of the classical Greek philosophers and characteristic events of their lives. Cugueró-Escofet and Fortin (2014: 435) confirm that perceptions and attitudes relating to fairness of outcomes, procedures, interpersonal treatment and information are indeed based on philosophical approaches. As would be illustrated later on, these aspects (fairness of outcomes, procedures, interpersonal treatment and information), are of special significance to the empirical research reported on in this article.

First of all, the scholarly fraternity inherited - from Socrates' legacy - the application of extensive rational thought through the dialectical method ( $c f$. Johnston 2011: 237; Souryal 2011: 4; Zistakis 1997: 526). Furthermore, the author would argue that Socrates emerged as an advocate for "community service". He taught in the marketplaces of Athens free of charge (Souryal 2011: 4), in contrast to the tradition of the Sophists who charged for their teaching (Jowett, sine anno): “"Evenus the Parian,' he replied; 'he is the man, and his charge is five minae." It was Plato, though, who professed that "each man must perform one social service in the state 
for which his nature was best adapted...A thing then, that in its contribution to the excellence of the state vies with and rivals its wisdom, its soberness, its bravery, is this principle of everyone in it doing his own task"; which principle is, in the words of Zdravkovic-Zistakis (1997: 516), "the principle of justice or justness".

Personal development, to one's full potential, was very important to Socrates. In an almost behaviouristic fashion, Socrates emphasised the significance of personal development and the pursuit of knowledge (wisdom) (Jowett, sine anno):

'Callias,' I said, 'if your two sons were foals or calves, there would be no difficulty in finding someone to put over them; we should hire a trainer of horses, or a farmer probably, who would improve and perfect them in their own proper virtue and excellence; but as they are human beings, whom are you thinking of placing over them?... [and] those of them who have now grown up and have become sensible that I gave them bad advice in the days of their youth...'

It follows that the work of classical fifth century philosophers such as Socrates, Protagoras and Plato, had a significant influence on the history of philosophy and especially a shift away from natural philosophy to a more humanistic philosophy and the way that people experience and construct their world (Internet encyclopedia of philosophy, sine anno). As the author will later argue, personal and spiritual growth is a sine qua non of the reform of incarcerated offenders. The influence of Socrates in this regard can be observed in Plato and Aristotle's philosophical observations about "justice" in years to come.

In what is perceived as controversial by some, Scolnicov states that Plato "is respectfully held in educational quarters as the philosopher of education" (Scolnicov 1997: 457). Plato, therefore, established the standards of education for guiding participation in a community and communal life (Zdravkovic-Zistakis 1997: 516). According to Cugueró-Escofet and Fortin (2014: 439), Plato was also one of the first philosophers, based on the dialogues of his mentor, Socrates, to focus on the importance of "justice" as "the most important requirement in social life to achieve goodness". Aristotle, who was in turn a pupil of Plato (Cugueró-Escofet and Fortin 2014: 439, 440), advocated that justice is essential "to facilitate the happiness of the citizens, which he considered the ultimate end of society", thereby focusing on the quality of social relationships between people, as well as citizens and the state:

...the personal virtue of justice is seen as a precondition for cooperation amongst people. Justice has been described as the main virtue that encompasses and balances the rest...as a necessary requirement for developing full human potential. (Cugueró-Escofet and Fortin 2014: 440)

Aristotle (Cugueró-Escofet and Fortin 2014: 439) believed that, as far as social relationships between citizens and the state are concerned, specific systems and mechanisms that would lead to "justice" need to be implemented through government, which the author would like to argue is inclusive of the philosophy 
and institution of modernistic criminal justice system(s), analogous to a "medical" approach. All members of society have a "fundamental obligation" to continuously develop and maintain their communities (Zistakis 1997: 525). Aristotle emphasised the significance of "injustice reparation" (cf. Cugueró-Escofet and Fortin 2014: 440): "A virtuous just person is encouraged to repair injustices as a part of performing that virtue of justice." Of significance in this regard is the fact that Aristotle also believed that "those who are 'different and not equal' must somehow 'be made equal’” (Gallagher 2012: 667). It was Plato's vision that this equilibrium needs to be reached - "which assigns everybody and everything its proper place and function, and [is] therefore a multiple model of truth, virtue and justice" (Zistakis 1997: 527).

As indicated by Stalley (1995: 19), "every aspect of the state must be geared to inculcating virtue which is understood as consisting in the harmony of the desires and appetites with right opinion. The city as a whole has a responsibility for training the characters of its citizens and that punishment plays an essential role in this process." Protagoras emerged as an exponent in the evolution of the penal theory in the form of punishment as an idiographic and a nomothetic deterrent, as well as crime prevention through socialisation (pro-social development) and education (cf. Stalley 1995: 1, 5, 10-12, 18):

...punishment is not inflicted by a rational man for the sake of the crime that has been committed, but for the sake of the future, to prevent either the same man or, by the spectacle of his punishment, someone else from doing wrong again. But to hold such a view amounts to holding that virtue can be instilled by education; at all events the punishment is inflicted as a deterrent education. (cf. Stalley 1995: 1, 13-14)

Plato (Stalley 1995: 2, 13, 14) generally concurred with the abovementioned view but, while Protagoras leaned more towards the interests of society, Socrates, Plato and Aristotle emphasised his belief in an epidemiological basis of "injustice as analogous to disease or even as actually being a disease of the soul”.

It is fitting that everyone under punishment rightly inflicted on him by another should be made better and profit thereby, or serve as an example to the rest, that others seeing the sufferings he endures may in fear amend themselves. (cf. Stalley 1995: 14)

It was Plato's view that the ultimate end of man and the state is dependent on moral virtue and that it is the responsibility of the legislator to educate citizens. Consequently, the primary objective of legislation is moral education and "when men investigate legislation, they investigate almost exclusively pleasures and pains as they affect society and the character of the individual" (Naddaf 2005: 48). Naddaf (2005: 48, 56), therefore, concludes that "education" in this sense is essentially about the "control" of pleasure and pain with the aim to reform the offender in character and conduct through punishment.

For Plato, education in this sense is based upon reason (Scolnicov 1997: 464). He emphasised social learning with his view that reason is something man has to 
become gradually accustomed to from an early age, and therefore emphasised that rationality is not a mere social convention. Society, however, bears the responsibility to develop reason through social learning, practices and conditions (Scolnicov 1997: 459).

For the citizens to be motivated to accept the 'rational principles' on which the laws are based, and consequently to follow the laws themselves, their feelings must be aligned to assist their laws... (Naddaf 2005: 48)

The words of Aristotle (in Howie 1968: 20): "For man the life of reason is the best and most pleasant, since reason more than anything is man", endorse this view.

The work of classical fifth century philosophers exerted, in the author's opinion, an indirect influence in later years on the work of distinguished penal and hedonistic proponents, such as Locke, Hobbes, Hume and Bentham (Souryal 2011: 127). Bentham (Souryal 2011: 167) advocated an ethical theory based on psychological hedonism in terms of which all persons are motivated by pleasure or pain. The principle of self-preference determines pleasure to be the goal of all people and the measure of all actions. The principle of utility (greatest happiness or greatest felicity principle) viewed "the morality of an act with the amount of happiness that act can yield to those whose interests are concerned" (Souryal 2011: 168). By adapting the principle to the needs of the community and the moral responsibility of the state, Bentham justified intervention by the state for the sake of social reform and to "provide maximum happiness to the largest number of citizens" (Souryal 2011: 168). For a person to make a morally correct decision, a system of measures is to determine the value of a diversity of pleasures and pains. Bentham (Souryal 2011: $169,170)$ formulated the hedonistic calculus according to which pleasure and painproducing actions are evaluated in terms of the degree of pleasure or pain, and based on the "characteristics of happiness" which can be measured in terms of intensity, duration, certainty, propinquity (delay in time or distance), fruitfulness, purity and extent.

The abovementioned philosophical principles advanced by the classical Greek philosophers are relevant to the criminal justice objectives of reparation and reform of those sanctioned by the state to make amends for their violations of social and legal norms and to restore the personal virtues of justice of those involved (personal and spiritual growth). In this regard, however, the focus would rather be on developing scholars (research participants) who are attempting to facilitate the latter, as well as an interest in their motives for "justice" as a psychological motive, "even if they have nothing personal to gain from it” (cf. Cugueró-Escofet and Fortin 2014: 436).

It is ironic though that the underlying context can be seen as the realisation of the Sophist ideal (cf. Johnston 2011: 237; Jowett, sine anno), as it is symbolised by contemporary universities (institutionalised higher education). However, and more 
reconcilable with the Socratic ideal, it focuses on the so-called "third mission" of universities.

\section{THE THIRD MISSION OF UNIVERSITIES}

Third mission activities of universities refer to "the restoration of a mission to engage with society in meaningful and mutually beneficial" ways and to "recognise anew an old social compact between universities and their host societies...to foster and promote it in partnership and collaboration" (Padfield 2012: 3), which may be reminiscent of the Sophist objectives of the fifth century BCE. Pusztai, Hatos and Ceglédi (2012) emphasise that the third mission of higher education must be taken seriously in view of the need for closer cooperation between higher education and industry. Indicators should take into account the long-term effects and added educational values, as well as students' commitment towards formal and informal ways to broaden their knowledge base through work for "public good" (Pusztai et al 2012: 8), which should be considered an important requirement of "justice" (cf. Cugueró-Escofet and Fortin 2014: 439).

\section{ATTAINMENT OF THE CORRECTIONAL MANDATE THROUGH COMMUNITY SERVICE BY VOLUNTEERS}

It stands to reason that overcrowding and poor prison conditions have enormous implications for any rehabilitation efforts made by the Department of Correctional Services (DCS) in South Africa. In its endeavour to advance past the rhetoric to fulfil its rehabilitative mandate, the DCS identified a new strategic direction to transform prisons into correctional centres of rehabilitation through the delivery of appropriate needs-based programmes within a holistic sentence planning context (White Paper on Corrections, The Department of Correctional Services, 2005). This corresponds with Plato's view that the ultimate end of man and the state is dependent on moral virtue, and that the legislator bears a responsibility to educate offenders through punishment with the aim of reforming offenders' characters and conduct.

The current curriculum for honours (fourth year) criminology students involves a module entitled "Criminological Evaluation and Assessment”. Students were invited to volunteer their services to assist with the assessment and profiling of sentenced offenders and, thereafter, with the compiling of a Correctional Sentence Plan (CSP) which will indicate which rehabilitation programmes are suitable for each offender. Not only is the service performed by the students of great value to the DCS - as it directly addresses the core function of the department as stated in the White Paper on Corrections - but the experiential learning opportunity has also expanded the students' learning experiences and knowledge and allowed for theory to connect 
with practice in terms of their exposure to the practical needs of offender care and the operational requirements of the DCS.

It is believed that the students' practical connections may lead to a "closing of the gap" between caring professions and improve the quality of service available to the DCS (cf. De Vos, Strydom, Fouché and Delport 2011: 45). This type of method fits in with the objective of research for human service professions as described by De Vos et al (2011) in that it has humanistic goals in the interests of the "public good" and "social goodness" as indicated above. It has also been confirmed that students who participate in community service as part of their studies, excelled in developing principled moral and reasoning skills; an aspect that was always emphasised by Socrates (Boss 1994: 2, 7).

The questions remain, however, as to what the motives of student volunteers for participating in the project would be, and what personal and institutional benefits this project would hold for their involvement.

\section{METHOD}

This article analyses the motives of the student volunteers participating in the project and the benefits that this project would hold for their involvement.

A case study approach was followed through the application of a qualitative survey as an exploration of the underlying social context. This was done in order to gain an understanding of the students' experience of the issues as underlying social phenomena and in terms of their exposure to the DCS (cf. Bachman and Schutt 2014; De Vos et al 2011).

Twelve students volunteered their services to assist with the assessment and profiling of sentenced offenders and with the formulation of sentencing plans in correctional centres in the provinces of Gauteng (Pretoria and Johannesburg areas), Limpopo and KwaZulu-Natal. A total of 249 assessments were eventually conducted by the student volunteers in these areas.

At the end of the academic year the volunteers were invited to provide insight into their experiences in the form of an online interview. The participants were ensured of their anonymity and confidentiality. Participants were requested to make, through their answers, a meaningful contribution to the project. An advantage of e-mail interviewing is the fact that no transcriptions need to be done as the data had already been collected in writing (Greeff 2011).

The author made use of online interviewing as an information-collection method, as it served as the most effective way to obtain pertinent information from the research participants through a direct exchange with an individual or group who possesses knowledge of the topic in question (DePoy and Gilson 2008). The researcher made use of open-ended questions within a semi-structured format to ensure that all the important facets of the study were covered. These questions provide the research 
participants with the opportunity to share their own responses descriptively without the restriction of categories. Delport and Roestenburg (De Vos et al 2011) confirm that a vast array of answers, depicting richness and self-expression, are prompted by open-ended questions. The collected data were organised to establish order, formation and meaning to the information gathered and to make sense out of textual data (De Vos et al 2011).

\section{RESULTS AND DISCUSSION}

The motives of the volunteers, inclusive of their personal experiences and the benefits this project holds for their involvement in the project, are displayed below.

\section{Motives of student volunteers}

Montesinos, Carot, Martinez and Mora (2008) identify three dimensions relevant to the third mission of higher education institutions, which can be reconciled with the collective views of the abovementioned classical Greek philosophers.

1. A social dimension is of relevance to this project through its commitment and volunteer contributions to society with no economic benefit.

2. An enterprising dimension emerges in the form of student volunteers who are providing feedback to the academic department and assisting in aligning curricula to societal needs. Of significance to the South African context is the fact that "services for developing countries fit perfectly within the enterprising third mission" (Montesinos et al 2008: 262).

3. An innovative third mission relates to development and innovation in specific industries aiming at the generation of "social networking and relational capital among the research community and industry” (Montesinos et al 2008: 263).

The following summary is reflective of the participants' initial motivations for partaking in the project:

- Many people are complaining about crime and no-one is doing anything to solve it.

- An ideal opportunity to understand theory and practice - to experience insight into the criminal justice system.

- For insight into criminology, criminal behaviour and the correctional environment.

- To gain valuable practical experience and skills.

- To apply knowledge.

- To be more than just an educated parrot. 
- To make a difference in the backlog (in assessments).

- To implement theories, to reach more potential in criminology.

- To assist the already overburdened correctional service.

- It is rewarding to meet the people behind the crimes.

It is evident that the central motives provided by the students relate to making a difference in society (with academic knowledge), to be able to link theory with practice, to gain practical experience in the field, and to enhance the students' understanding of criminological knowledge with their proposed involvement in this project:

I have always had an interest in the phenomenon of crime and its related issues. Criminology, in my opinion, is the best subject to educate you in all facets of crime, offenders and the judicial system. I would use the unique knowledge I have gained from this subject to apply it practically...

\section{Emergent motives of volunteers}

Aguire and Bolton (2013) mention three general categories of motivation for, especially, crisis volunteers, namely altruism, personal fulfilment, and personal growth. They mention that the "mixture of altruism and egoism is supported by the literature on volunteer motivations and is grounded in the literature on individual motivations” (Aguire and Bolton 2013: 328). In Aguire and Bolton's (2013) qualitative interpretive meta-synthesis of five qualitative studies, six overlapping and interactive themes emerged: (1) internal motivation to make an external difference; (2) volunteer existentialism; (3) lived experience; (4) internal/personal fulfilment; (5) lack of support; and (6) lack of direction.

Although overlapping to a certain extent, the following extracts serve to indicate that the motives of the volunteers can also be categorised in terms of the same themes.

\section{Internal motivation to make an external difference}

The following relevant views were expressed by the volunteers:

- I found that being involved in the offender assessment helps to link theory to practice and make the experience of studying more fulfilling - and to learn and experience the offenders as individuals themselves.

- I believe the involvement in the project goes towards establishing credibility for yourself as a student of criminology. In order to be a good criminologist I believe that theory and practice need to work hand in hand. One without the other is incomplete. 
- I found that I have to be more involved and make a greater effort to get to the prison between studying. The work load is unbelievable, and assistance is greatly appreciated.

- I also thought that I am in this department for experience only and then leave, but now I feel like I can stay in this department as much as I can, because I am really enjoying what I'm doing.

It is clear from the abovementioned excerpts that the participants are driven "internally" by a combination of altruism and egoism, a holistic approach to the assignment, as well as reparation; giving back to the community by the offenders as well as the participants, although for different reasons.

\section{Volunteer existentialism}

The volunteers are of the belief that:

- On a personal level it is helping me understand the dire situation in the South African prisons.

- I learned to look at the person - not the crime.

- ....and not just thinking about them as criminals.

- Working with offenders, I realised that there is a chance for rehabilitation, for some. I understand why some individuals commit crime.

It is clear that the participants achieved more insight into the "human condition", social and individual interconnectedness, as well as a sense of community involvement.

The combination of participants' internal motivation to make a difference as well as their "volunteer existentialism" as a "lived experience" seemed to have an effect on the participant as a person.

\section{Lived experience}

It is evident from the following excerpts that the participants developed selfawareness, personal growth and consequently personal change:

- Practical experience linked to my studies. It is hands-on, which you cannot learn from a book. It is also real life, real offenders, with real problems and issues.

- Gaining of experience and "mind growth" towards exploring different working methods and practice in correctional service.

- I found that being involved in offender assessment helps to link theory to practice and makes the experience of studying more fulfilling. 
- It has helped me see the different aspects of the criminological study. I have seen how someone with a passion for the prison system could work there.

\section{Internal/personal fulfilment}

The following excerpts indicate attitudes of altruism, personal fulfilment, motivation to develop and train offenders, and to bring about change; but also personal change as a result of personal experiences among the participants:

- At first, the environment was scary, but now I am enjoying it because I'm working three days a week.

- I have really enjoyed partaking in this project thus far and for me personally it has been very rewarding.

- Through speaking to the offenders, the devastation of drug and alcohol abuse has become a living reality to me. The havoc that AIDS has wreaked in terms of child-headed households turning to crime as a means of survival, coupled with minimal or no education, has been a real eye-opener to me.

\section{Lack of support and direction}

Yanay and Yanay (in Aguire and Bolton 2013) identified a lack of direction, and linked to it the lack of support as inhibitors for volunteers. In this study, demotivators of this nature also emerged:

- The staff members that are currently doing the assessments (not all, but some and in my opinion) have not been adequately trained and the forms completed are either incorrectly completed or incomplete. In my opinion, this impacts negatively on the accuracy in terms of assessing the risks and needs of the offender initially and, in the long term, effective rehabilitation is affected.

- I felt a bit discouraged and that my help was no longer needed as there was nothing for me to assist with. I felt that I was in the way and no one really knew what to do with me next.

- As part of the training we were supposed to have mentors at the correctional centre/s, but we were literally given the files and left to conduct the assessments.

- I suspect this could be a reason why there are not more honours students participating.

What is of significance, however, and despite the abovementioned negative experiences, the participants developed feelings of admiration and empathy for the correctional officials rather than developing negative feelings towards them. 
- I understand that the Department of Corrections needs more funds and volunteers to help out with the extensive work load. There are many strategic plans and procedures but it proves to be impossible to implement without the relevant [re] sources.

- They seem to manage under the circumstances. It is definitely an eye-opening experience and I would like to assist where I can.

Furthermore, these aspects have influenced the participants positively as far as the necessity of the project is concerned.

- I found that I have to be more involved and make a greater effort to get to the prison between studying. The work load is unbelievable, and assistance is greatly appreciated.

- At first, I thought that offenders were not like other people, but since my involvement with DSC I can see that they are human beings who need guidance in terms of taking decisions. Secondly, I also thought that I am in this department for experience only and then leave, but now I feel like I can stay in this department as much as I can, because I am really enjoying what I'm doing.

- I thought that the main purpose of this project was for students to gain some practical experience by "kindly helping out" in that regard, but since then, having been into the prison to do the assessments, I have realised that a very real need exists within the DCS for this help. The DCS is very under-staffed and have very little resources at their disposal to be able to carry out this vital function properly.

- It made the pages of my study guides and textbooks come alive! Through speaking to the offenders, the devastation of drug and alcohol abuse has become a living reality to me. The havoc that AIDS has wreaked in terms of child-headed households turning to crime as a means of survival, coupled with minimal or no education, has been a real eye-opener to me.

\section{CONCLUSION}

The abovementioned serves to illustrate how the project manages to bridge difficulties pertaining to the third mission of the academic institution involved on a national as well as a regional basis, benefitting the student volunteers and the DCS as a department, as well as the inmates involved and society in general (cf. "public good"). The elements of third mission activities identified by Laredo (2007), which are reflected in this project, are:

- The transfer of competences and mission-oriented public service.

- Knowledge co-production and circulation to industry. 
- Involvement of the university in societal life.

- Interaction with society.

It emerged from this research that the participants' motivation to become involved in the project was strong enough to overcome any stressors inherent to the DCS milieu. By allowing the participants to conduct their assessments, it led to a greater understanding among them and led to empathy for the difficult and unappealing conditions in which correctional officials have to work. In support of the literature (see Aguire and Bolton 2013), the general categories of motivation for crisis volunteers, namely altruism, personal fulfilment, and personal growth, were also confirmed by this project. It also confronted the participants with the realisation of the existence of "alternative" communities and conditions, other than their own, and an interconnectedness and obligation towards them.

The question, of course, arises as to the relevance of Greek philosophy in this regard. This is answered by Mkhatshwa (2005: 3) where he confirms that: "The enduring legacy of Greek philosophy is enquiry to determine possible solutions to life's challenges. Of course, most of the concerns of Greek philosophy seem abstract, though closer scrutiny reveals a direct correlation with matters concrete.”

The abovementioned activities can be reconciled with some of the world views of the classic Greek philosophers mentioned in this article, such as Socrates' view that the purpose of human life was personal and spiritual growth; "self-actualisation" in terms of an individual's personal development to one's full potential, and the pursuit of "knowledge" through the Socratic method to attain "justice", as "the most important requirement in social life to achieve goodness". As indicated, Aristotle supported the view that justice is essential "to facilitate the happiness of the citizens, which he considered the ultimate end of society", thereby focusing on the quality of social relationships between people as well as citizens and the state (cf. CugueróEscofet and Fortin 2014; 439, 440); which, in the author's view, contains some of the elements of modernistic criminal justice philosophy and institution in which fairness of outcomes, procedures and interpersonal treatment receive specific attention.

These aspects correlate with the general principles advocated by fifth century Greek philosophers supra that punishment should, therefore, be future oriented and not punitive, but reformist in nature instead of pursuing vengefulness and retaliation, which should not form part of punishment (Stalley 1995: 5-7). In Socrates' view (cf. Ladikos 2006: 76), "the function of justice is to improve human nature and moreover justice is a form of goodness that, by its very nature, cannot participate in anything injurious (vengeance) to someone’s character.”

Consequently, Mackenzie (Stalley 1995: 15) contextualises the goal of punishment as "primarily intended to educate men in the business of being moral". Also see Naddaf (2005: 48, 56). It can thus be said that teaching virtue was largely a matter of character training during this time frame (Stalley 1995: 18), and to be 
achieved through "training in the Socratic dialectic" (Taylor in Stalley 1995: 18). As Stalley (1995: 16) concludes, "a means of inculcating virtue is clearly not just a matter of achieving outward conformity with the law, but requires some form of inner harmony or adjustment.” According to Ladikos (2006: 74, 77), and contrary to the social attitudes of the time, Plato "completed the internalisation of justice" as a quality of man by introducing the "virtue of the psyche" of the human personality, thereby enhancing the complexity of "justice" and the cumulative responsibility of society and the state in terms of "injustice reparation" (cf. Cugueró-Escofet and Fortin 2014: 440), according to which "A virtuous just person is encouraged to repair injustices as a part of performing that virtue of justice"; in this case the research participants.

Plato's proclamation that "conscience is the sovereign to which we must submit if we are ever to become men of worth" (Zistakis 1997: 537), is probably the most important principle in this regard. As Zistakis (1997: 531) rightly points out:

One cannot judge others and their actions without constantly judging himself/herself. The faculty of judgement contains and brings about the uniquely human mode of consciousness: self-consciousness. One cannot be capable of judging anything or anyone without being self-conscious, just as he/she cannot have any consciousness without judgement. Selfconsciousness is, in a way, pure judgement. More precisely, it is a paradigm and embodiment at the same time.

\section{LIST OF REFERENCES}

Aguire, R.T.P. and Bolton, K.M.W. 2013. Why do they do it? A qualitative interpretive metasynthesis of crisis volunteers' motivations. Social Work Research, 37(4): 327-338.

Bachman, R. and Schutt, R.K. 2014. The practice of research in criminology and criminal justice (5th edition). London: SAGE.

Boss, J.A. 1994. The effect of community service work on the moral development of college ethics students. Higher Education, 23(2): 183-196.

Cugueró-Escofet, N. and Fortin, M. 2014. One justice or two? A model of reconciliation of normative justice theories and empirical research on organizational justice. Journal of Business Ethics, 124: 435-451.

Department of Correctional Services. 2005. White Paper on Corrections. Pretoria: Government Printers.

De Vos, A.S., Strydom, H., Fouché, C.B. and Delport, C.S.L. 2011. Research at grass roots: For the social sciences and human service professions ( $4^{\text {th }}$ edition). Pretoria: Van Schaik.

DePoy, E. and Gilson, S. 2008. Healing the disjuncture: Social work disability practice. Comprehensive handbook of social work and social welfare, 1:13.

Gallagher, R.L. 2012. Incommensurability in Aristotle's theory of reciprocal justice. British Journal for the History of Philosophy, 20(4): 667-701. 
Gerzon, R. 2011. New foundations. Available at http://www.consciousearth.us/socratesunexamined-life.html (accessed 5 February 2015).

Greeff, M. 2011. Information collection: Interviewing. In A.S. de Vos (Ed.), H. Strydom, C.B. Fouché and C.S.L. Delport. Research at grass roots: For the social sciences and human service professions ( $4^{\text {th }}$ edition). Pretoria: Van Schaik.

Howie, G. 1968. Aristotle on education. New York: Macmillan.

Internet encyclopedia of philosophy. (Sine Anno). Protagoras. Available at: http://www.iep.utm. edu/protagor/ (accessed 20 April 2015).

Johnston, D. 2011. A brief history of justice. United Kingdom, Oxford: Wiley-Blackwell.

Jowett, B. Sine Anno. The Apology: from The dialogues of Plato. Volume 2. Available at http:// law2.umkc.edu/faculty/projects/ftrials/socrates/apology.html (accessed 22 March 2015).

Ladikos, A. 2006. The pursuit of justice in Plato's Republic. Phronimon, 7(2): 73-88.

Laredo, P. 2007. Revisiting the "third mission" of universities: Toward a renewed categorization of university activities. Higher Education, 20: 441-456.

Mkhatshwa, S. 2005. Address at the South African Society for Greek Philosophy and the Humanities Conference on Ethics, Politics, Criminality: Perspectives from Greek Philosophy and Africa, Tshwane, 4 May. Phronimon, 6(1): 3-6.

Montesinos, P., Carot, J.M., Martinez, J-M. and Mora, F. 2008. Third mission ranking for world class universities: Beyond teaching and research. Higher Education in Europe, 33(2/3): 259271.

Naddaf, G. 2005. Ethics, politics, and criminality: Plato's cosmological perspective. Phronimon, 6(1): 45-57.

Padfield, C. 2012. Green Paper. Fostering and measuring "third mission" in higher education institutions. Available at: http://e3mproject.eu/docs/ Green\%20paper-p.pdf (accessed 20 January 2014).

Pusztai, G., Hatos, A. and Ceglédi, T. 2012. Third mission of higher education in a cross-border region. Educational research in central and eastern Europe. Hungary: University of Debrecen: Center for Higher Education Research and Development.

Scolnicov, S. 1997. Plato and modern education. In Plato's philosophy of education and its relevance to contemporary society and education in the ancient world (pp. 457-465), Volume 2, edited by J. D. Gericke and P.J. Maritz. Pretoria: SASGPH.

Souryal, S.S. 2011. Ethics in criminal justice: In search of the truth (5 $5^{\text {th }}$ edition). Burlington (USA): Anderson.

Stalley, R.F. 1995. Punishment in Plato’s “Protagoras”. Phronesis, 40(1): 1-19.

Zdravkovic-Zistakis, A. 1997. Why education now? Philosophy and politics. In Plato's philosophy of education and its relevance to contemporary society and education in the ancient world (pp. 513-520), Volume 2, edited by J.D. Gericke and P.J. Maritz. Pretoria: SASGPH.

Zistakis, A. 1997. Philosophy, education and the raising of the political consciousness: A reading of Plato's Republic. In Plato's philosophy of education and its relevance to contemporary society and education in the ancient world (pp. 521-537), Volume 2, edited by J.D. Gericke and P.J. Maritz. Pretoria: SASGPH. 